\title{
Dito(s) de vida e morte em Campo geral
}

\author{
Maria Theresa Abelha Alves ${ }^{1}$ \\ Eu me nomeio, é como se eu pronunciasse meu canto fúnebre: \\ eu me separo de mim mesmo, não sou mais a minha presença nem minha realidade, \\ mas uma presença objetiva, impessoal, a do meu nome, \\ que me ultrapassa e cuja imobilidade petrificada faz para mim \\ exatamente o efeito de uma lápide, pesando sobre o vazio. \\ (BLANCHOT, 1997, p.312).
}

A novela "Campo Geral”, primeira de Manuelzão e Miguilim, expõe, a um só tempo, com delicadeza e contida violência, a questão da morte, que é o ponto crucial de toda a filosofia, constituindo-se em sua origem e sua causa. Como bem observou Arthur Schopenhauer, ela "é propriamente o gênio inspirador, ou a musa da filosofia (...). Dificilmente se teria filosofado sem a morte" (SCHOPENHAUER, 2000, p.59). Por focalizar a indesejada das gentes, Guimarães Rosa cria na linguagem e a partir dela sua própria metafísica pessoal, e a novela que dessa tarefa criativa resulta pode ser considerada como prosa de cunho filosófico, em que aquele que fala é aquele que morre.

Se Epicuro, ao conceituar o ser, fizera a oposição vida/morte, elucidando um termo pela inexistência do outro - "Se se é, ela não é; se ela é, não se é" - e se, bem mais tarde, Wittgenstein, seguindo-lhe as pegadas, observava que "A morte não é um acontecimento na vida: não vivemos para experienciar a morte" (HOWARTH / LEAMAN, 2001, p.290), é porque ambos reconheceram que só se pode ter acesso à morte de outro, a própria morte é uma impossibilidade para o sujeito pensante. Contudo, o grande paradoxo da existência humana é que a permanente possibilidade do ser se inscreve na sua permanente impossibilidade. A filosofia contemporânea, pós Heidegger, principalmente a escola francesa, tem evidenciado tal paradoxo. A morte é o mais fecundo paradigma da negatividade produtiva. Nesse sentido Georges Bataille, Emmanuel Lévinas, Maurice Blanchot e Jacques Derrida pensam a morte como acontecimento ambíguo.

Bataille vê a morte como uma negatividade que pode ser administrada produtivamente num processo dialético, de modo que essa recuperação produtiva oculte a morte enquanto impossibilidade ou perda irrecuperável. O filósofo propõe o que se pode considerar como uma economia da perda não produtiva que, a um só tempo, subjaz e extrapola a economia produtiva, de modo que a perda material seja compensada por ganhos simbólicos. Em "Campo Geral” tal

\footnotetext{
${ }^{1}$ Professora titular aposentada da Universidade Estadual de Feira de Santana. E-mail: posldc@uefs.br
} 
economia se manifesta: morto Dito, Miguilim se torna capaz de o dizer, numa troca vantajosa entre o material e o simbólico.

Lévinas reconhece que a morte confronta o sujeito com algo completamente diferente de si. Morrer é deixar de ser capaz. Mas tal consciência o sujeito só adquire com a morte de outro. É da relação primária com o outro enquanto mortal que Lévinas deriva a noção de responsabilidade ética imposta pela mortalidade do outro. Assim, à negatividade representada pela falência total dos órgãos de alguém, corresponde o compromisso que perante tal falência o sobrevivente, imperativamente, adquire. Em "Campo Geral”, Rosa parece reproduzir a filosofia de Lévinas, na atitude comprometida de Miguilim face à morte do irmão.

Para Blanchot, por exemplo, a morte é assimilada à potência mortífera da linguagem. Para este filósofo, o real só se pode dizer mediante a linguagem que o nega em sua efetiva existência. Assim, a morte do real pela linguagem é a fonte de uma finitude produtiva e inaugural que permite a emergência possível do significado e até da consciência. O lugar onde a negação efetuada pela linguagem se transforma em afirmação permanente e renovada do que nega é a literatura, lugar privilegiado em que os pólos princípio e fim, vida e morte interagem em dinâmica e inesgotável reciprocidade. Na literatura, a negação da realidade, efetivada pela linguagem, nunca é definitiva, nunca se completa, pois dá vida à própria realidade a que se refere.

Derrida usa a noção de morte como paradigma da negatividade, da ausência. Assim, o discurso permanece significativo mesmo quando alienado de seu emissor ou receptor, numa ausência que não impossibilita a comunicação, muito pelo contrário, ajuda-a em seu ser fecundante. Em “Campo Geral”, Miguilim é o receptor dos ditos de Dito, sobrevivente à ausência e finitude deste, torna-se a memória que detém, ordena, requer e delega a herança irrevogável deixada pelo irmão.

Guimarães Rosa parece compactuar da concepção de morte desses filósofos, isto é, morte como uma negatividade que se pode contabilizar produtivamente num intercâmbio perene, num deslizamento inquietante entre ser e não ser, realidade e irrealidade, presença e ausência, lembrança e esquecimento. Através da morte de muitos personagens, o mineiro, para quem os mortos ficam encantados, oculta a questão da morte enquanto impossibilidade e, simultaneamente, recupera-a em sua forma produtiva e potencialmente criadora. A morte de personagens rosianos transmuta a negação da linguagem em afirmação contínua, assim o movimento de negação por que os personagens são exibidos como seres morrentes, paradigmas do drama da absoluta ausência, tornase o movimento de afirmação ao fazê-los conhecidos, submetidos e comunicados, conferindo à impossibilidade acarretada pela finitude a sua emergente possibilidade de não morrer. É o que 
ocorre em "Campo Geral”, texto que se pode considerar como póstumo, pois tecido sobre a lápide de Dito, e é só a partir dessa lápide que se constitui:

\begin{abstract}
A literatura, como a palavra comum, começa com o fim que, somente ele (o fim), permite compreender. Para falar, devemos ver a morte, vê-la atrás de nós. Quando falamos, nós nos apoiamos num túmulo, e esse vazio do túmulo é o que faz a verdade da linguagem, mas ao mesmo tempo o vazio é a realidade e a morte se faz ser. (BLANCHOT, 1997, p. 323).
\end{abstract}

A novela, desde o princípio, mostra-se íntima da morte, ao eleger para morada de Miguilim, seus pais e seus irmãos um espaço que os parece enterrar vivos. Este espaço se situa "em ponto remoto", "no meio dos Campos Gerais", "num covoão em trecho de matas", considerado pela Mãe “o triste recanto”. A situação geográfica do lugar se faz mediante vocábulos que, além da forma substantiva com que se apresentam, admitem, se tomados como verbo, significados associados à morte. Assim, sobre serem descritivos, termos como "morro", "mato", "mata" são insistentemente convidados à composição semântica da novela, ajudando a sugerir a atmosfera de morte, que se torna mais acentuada pelo fato de o local que instauram ser um "lugar distante de qualquer parte", onde "chove sempre” e era "tudo tão sozinho, tão escuro" (465). Este espaço é isolado, ermo, feio, e opressor e se torna mortal aos amores clandestinos da Mãe. O mato esconde a ameaça de destruição da família, pois lá se oculta o Tio Terez, isto é, a iminência de morte simbólica do Pai. É lá que Patori mata e morre. É lá que o Pai assassina o companheiro de trabalho, transformado em rival, Luisaltino, e, posteriormente, se enforca.

Nota-se o poder corrosivo da narração através da matéria lingüística utilizada: provérbios e aforismos, conceitos cristalizados em falas populares, reprodução de trovas e versos. Todo esse material compõe o pano-de-fundo que instrui a vida no sertão, condicionando-lhe doxa e práxis. A narração se constitui memória póstuma aos acontecimentos que narra sobre a infância de Miguilim que transcorrera pontuada pelos ditos de Dito.

O tempo da enunciação é posterior ao tempo do enunciado. A memória narrativa retoma retrospectivamente os acontecimentos, numa forma circular. A novela começa com a viagem feita por Miguilim, em companhia de Tio Terez, para ser crismado em Sucuriju, "por onde o bispo passava" (p.465), e termina com a despedida de Miguilim da família, para empreender uma outra viagem para a cidade de Curvelo, já agora em companhia do doutor José Lourenço que lhe emprestara óculos para fazê-lo enxergar melhor e que haveria de lhe abrir os olhos para outras coisas, pois ia pô-lo na escola e fazê-lo aprender um ofício. A vida simbolizada pela viagem é uma tópica recorrente na literatura. O destino individual surpreendido em trânsito constante é tema muitas vezes explorado por Guimarães Rosa, ele que a si mesmo dera o epíteto de homo viator. Fiel 
mais uma vez a essa tópica, Rosa organiza a estória de "Campo Geral" entre uma viagem e outra. É nesse intervalo que se processa o presente do enunciado, quando Miguilim já tinha oito anos. A primeira viagem já é acontecimento passado, tanto para o enunciado quanto para a enunciação, já que se dera quando o menino completara sete anos. Miguilim é surpreendido sempre numa situação de trânsito, marcada por partidas e chegadas, nascera em Pau Roxo onde passara os primeiros anos, depois viera para o Mutum, do Mutum partira para Sucuriju e regressara ao Mutum de onde haveria de partir para a cidade. Durante o tempo do enunciado, está em constante estado de passagem: entre o dentro e o fora da casa, entre o espaço do quintal e a mata. É este estar sempre em viagem que the possibilita a observação e a escuta.

Para Blanchot, a memória que retoma os acontecimentos consiste numa entrega fascinada à ausência do tempo, pois o que foi uma vez não será nunca mais. É nessa ausência de tempo que o narrador mergulha: o que foi não é, simplesmente retorna como já e sempre passado, surge, portanto, como lembrança, volta por intermédio da linguagem, porém como morto. O fascínio da ausência promove o encontro do passado morto com o presente vivo, paradoxalmente reúne polos conflitantes numa persistente ambiguidade: "O tempo morto é um tempo real em que a morte está presente, chega mas não cessa de chegar, como se, ao chegar, tornasse estéril o tempo pelo qual pôde chegar" (BLANCHOT,1997, p.21).

Sabemos que Rosa não escolhia o nome de seus personagens em vão. Dito, nome do irmão de Miguilim, morto na infância por tétano e cujas cerimônias fúnebres servem para evidenciar o lado social da morte, é significante que além do significado de nome próprio corresponde ao particípio passado do verbo dizer. Assim, na senda de Blanchot, Dito (ou o dito) é, a um só tempo, a imagem da morte e a chance única de não morrer. A novela ilustra a sintonia tanto mais efetiva quanto mais incontornável entre palavra (dito) e morte.

Dito é enigmático, indefinido: tem um saber das coisas que excede sua pouca idade, percebe por premunição tudo que ocorre em casa: "O Dito era menor mas sabia o sério, pensava ligeiro as coisas, Deus tinha dado a ele todo o juízo" (p.470), ora diz com clareza o que pretende comunicar, ora usa uma linguagem obscura e cifrada. Miguilim não o consegue decifrar, embora tente em vão o apreender. Dito é diferente das demais crianças, e deixa Miguilim sempre com uma interrogação: "Mas por que era que o Dito semelhava essa sensatez - ninguém não botava o Dito de castigo. O Dito fazia tudo sabido, e falava com as pessoas grandes sempre justo, com uma firmeza" (p.490) A intenção de decifrar Dito é sempre frustrada, porque é de sua própria natureza (natureza do dito em minúscula) ao afirmar-se existente, afirmar-se morto e, ao afirmar-se morto, afirmar-se infinitamente aberto. 
A novela exibe essa característica ambígua da linguagem através de várias estratégicas. Em primeiro lugar, patenteia-se que a verdade do dito pode mudar em conformidade com o falante, é o que ocorre com a expressão “É meu!" (p.467), no caso do peru. O Menino Grande profere esse dito por ser o efetivo dono da ave, Miguilim o repete para agradar, mas o Menino Grande se sente ameaçado em sua posse e ataca Miguilim com pedradas. Por outro lado, o dito muda de significado quando muda de referente, como, por exemplo, no nome dos cães e do reprodutor da boiada: “Zé Rocha" e "Julinho da Túlia" (p.469) eram desagravos do pai de Miguilim, o sentido primeiro desses ditos, nome de pessoas, morre ao serem eles atribuídos a animais. O mesmo ocorre com "Rio Negro" (p.489), que de rio passa a touro, ou com os nomes que Patori atribui ao sexo dos bois e dos cavalos: "verga" e "província" (p.493).

Os inúmeros aforismos e frases feitas que a novela apresenta são ditos congelados que já perderam sua condição de imagem e são, por isso mesmo, outros tantos ditos mortos, mas que estão prontos a adquirirem novos significados a depender de quem os diz, para quem são expressos, em que contextos são proferidos. Isso ocorre quando Miguilim rasga sua roupa e o Pai ordena-lhe que tire as calças e fique nu em frente a todos, enquanto a Mãe lha costurava, o menino pensa: "Só isso, se morria de vergonha” (p.490), ou quando o Pai, explicando que não tinha condições de conseguir um touro melhor que o Rio-Negro, dizia "Que de pobres iam morrer de fome” (p.490). Quando Miguilim diz “morrer de vergonha”, a expressão mantém sua base metafórica, porém o Pai, quando se mata, de fato morre de vergonha por sua condição de homem destinado a ser sempre traído. De igual forma, quando o Pai diz “morrer de fome”, a expressão não pode ser compreendida fora de seu caráter metafórico, no entanto é a mesma expressão que será usada para explicar a morte de Patori, e, aí o sentido deverá ser tomado ao pé da letra: “Tinham achado Patori morto, parece que morreu mesmo de fome, tornadiço vagando por aquelas chapadas" (p.513). As expressões congeladas, "morrer de vergonha" e "morrer de fome", são empregadas intencionalmente: de um lado documentam o poder da linguagem de re-significar-se, de outro, faz referência a seu aspecto letal.

A novela torna patente a relação estreita entre linguagem e morte, tão bem representada pela sabedoria grega que derivou os vocábulos fonema e funéreo da mesma raiz (foné/funé) e concedeu à palavra sema um duplo sentido: significado de um termo e pedra tumular. Assim todo o dito está inexoravelmente perto da morte, porém é do vazio do túmulo que se ergue. Só o recado não dado, o dito que não encontra receptor, é que não morre. Assim a carta escrita por Tio Terez endereçada à Mãe e que Miguilim não faz chegar ao destinatário se torna inofensiva para emissor e receptor. Só o canal de veiculação - no caso Miguilim - se expõe ao caráter funesto do dito, pois fica infeliz e confuso, julgando ter traído a amizade e a confiança do tio de quem muito gostava. 
"Campo Geral" ilustra as características linguísticas do dito e suas funções. Ele pode ser usado para apresentar ou encobrir uma realidade em função do que pensam os interlocutores. Miguilim fica doente e julga que é por causa da árvore do jardim ter ultrapassado o teto da casa, obedecendo a uma crença popular. Dito, instruído pelo mesmo quadro referencial, compactua da crença de Miguilim e manda cortar a árvore. Ao desculpar-se com o Pai, o menino diz uma mentira que o ouvinte recebe como verdade. Eis o fingimento tão caro aos poetas posto em evidência. Dito, dono da palavra, dono da linguagem que o qualifica, age com aquela "honestidade" própria do escritor e da literatura, pois "na literatura o engano e a mistificação são não apenas inevitáveis, mas também formam a honestidade do escritor, a parte de esperança e de verdade que existe nele" (BLANCHOT, 1997, p.300).

Miguilim reconhece que a palavra, na sua função de apresentar, é o que concede existência ao que apresenta. Assim, contra a opinião da Nhanina de que o Mutum é um lugar feio, deseja contrapor as palavras do homem do Sucuriju que julgara bonito o lugar. Por isso pensa que ao regressar teria "a boa notícia para dar à mãe: o que o homem tinha falado - que o Mutum era lugar bonito... A mãe, quando ouvisse essa certeza, havia de se alegrar, ficava consolada" (p.465). Miguilim dá-se conta do valor linguístico da frase declarativa, isto é, o de instaurar uma certeza. Por outro lado, a crença de Miguilim de que o homem tinha razão, deve-se a outro fator importante: o ideológico. A linguagem veicula ideologias, valores, sentimentos, emoções. Os ditos seriam tanto mais verdadeiros quanto mais isentos fossem. Intuindo que sua mãe tem razões secretas para não gostar do Mutum, o menino acredita ser verdade a fala do homem do Sucuriju "só pela maneira como o moço tinha falado: de longe, de leve, sem interesse nenhum; e pelo modo contrário de sua mãe" (p.466).

Como habitante do sertão que é, Miguilim acredita na magia das palavras, confere a elas um poder superior de dar vida e morte, pois crê que a posse das palavras lhe assegura o domínio sobre as coisas, sobre o mundo físico e metafísico, por isso, ao se sentir doente, reza e não fala a ninguém o que está sentindo: "a reza era só para ele conseguir de não morrer, e sarar. (...) Falasse, os outros podiam responder que era mesmo; falasse, os outros então aí era que acreditavam a mortezinha dele certa, acostumada" (p.485). O protagonista experimenta nessa passagem a magia da linguagem, sua ambiguidade, ao mesmo tempo tranquilizadora (o poder mágico da reza) e terrível (o poder mágico atribuído à linguagem dos outros), porque vivencia no ato de dizer uma maravilha inquietante.

Outro aspecto que a novela aborda concerne ao caráter aleatório do signo linguístico. Havia um gato na casa, e Tomezinho era incapaz de dizer gato, palavra que os irmãos mais velhos lhe queriam ensinar. Conseguia apenas dizer "quó", então o gato passou a chamar-se "Quóquo". 
Miguilim questiona: "Por que não botavam nele nome vero de gato nas estórias: Papa-Rato, Sigurim, Romão, Alecrim-Rosmanim ou Melhores-Agrados? Se chamasse Rei-Belo... Não podia?” (p.474). O que o questionamento do menino esclarece é que todos esses nomes "veros" são tão arbitrários quanto o nome que o irmão caçula dera ao gato. Atribui-se também aqui um deslocamento do signo. Tomezinho não consegue dizer gato, com sua linguagem infantil, mas diz "Quóquo", termo que os falantes pequeninos do português do Brasil utilizam para nomear galo. Entre "gato" e "galo" só há um traço distintivo, que a fala da criança consegue destruir.

A novela exacerba a função metalinguística, pois Miguilim está sempre perguntando o que as palavras querem dizer e há sempre alguém que lhe responde e lhas explica: "Rosa, que coisa é a gente ficar héctico? - Menino, fala nisso não. Héctico é tísico, essas doenças, derrói no bofe, pessoa vai minguando magra, não esbarra de tossir, chega cospe sangue...” (p.487). Quando a semântica da palavra não pode ser expressa por um sinônimo, a explicação vem por meio de aproximações comparativas: “'Que é que é teatro, Mãe?’ - Miguilim perguntara. '- Teatro é assim como no circode-cavalinhos, quase...' " (p.477), e quando as comparações são insuficientes para elucidarem o significado do significante desconhecido, são acompanhadas das onomatopeias, estas que são ditos motivados: “'Que é que é flauta, Tio Terez?’ Flauta era assovio feito, de instrumento, a melhor remedava o pio assim do sanhaço grande, o ioioioim deles". (p.487).

A dimensão metalinguística também se expressa na tensão entre o escrito e o oral. Se há um narrador que em terceira pessoa apresenta os fatos, há também os personagens cujas vozes são reproduzidas ou nos diálogos, ou através do estilo indireto livre. Esse processo permite a Guimarães Rosa a relação profunda que se verifica em seu personalíssimo estilo entre escrita e oralidade. A oralidade se marca nesta novela por meio das frases feitas, dos provérbios, das crendices populares, enfim, por meio de ditos cristalizados e, porque cristalizados, mortos e prontos a se tornarem outra vez significativos e originais. A novela ao tratar da morte de Dito, é do extraordinário poder da linguagem que trata: o poder mortífero e fecundante do dito.

A novela empreende a discussão metalinguística e, concomitantemente, encena uma tragédia, mediante um dizer sem querer dizer que anuncia a morte, mediante enigmas que se colocam à decifração e previsões que se podem realizar, de modo que palavra, silêncio e morte interajam. A realidade da família que vive encovada nas terras perdidas do Mutum se conta através de uma linguagem insinuadora, como a dos antigos oráculos, que parece querer anunciar e afastar o perigo iminente da morte, quer a morte simbólica do Pai pela relação adúltera da Mãe, quer a morte física do rival que o caráter violento do Pai faz supor. Adotando uma linguagem que anuncia a morte, a novela comprova o caráter inquietante do desconhecido que só na letra se constrói. Há uma tragédia emergente que a linguagem oculta e desvela mediante frases que não se concluem e 
que permanecem reticentes: tragédia de amor e morte que se pretende alcançar em meio ao torvelinho indefinido de lacunas significantes, que sugerem que toda linguagem só pode começar com o vazio.

Essa constante ameaça se insinua nas inúmeras caçadas que os homens do lugar fazem aos animais: caçada ao tatu, à cobra urutu, ao coelho, aos pássaros com as arapucas, ao tamanduá bandeira que pegou o Julim, pois "em todo dia, também, arrastavam os bichos matados, por caça" (473); pelos relatos de irreparáveis perdas: perda de pingo-de-ouro, perda da cuca do menino; pela agressividade do Pai. Todas essas passagens se formam por ditos que prefiguram ou encobrem outros ditos, num processo fecundo de possibilidades especulares. Caçadas de animais se equivalem a caçadas de homens; mortes de animais se equivalem às de pessoas; as perdas remetem às frustrações de sonhos, de amores, de esperança.

A morte anunciada está na origem da grande tragédia do homem, a tragédia de seu destino infeliz. O homem só é homem porque capaz de saber-se mortal. É essa terrível ciência que eleva o existente à categoria de ser. A morte está no homem como sua parte mais humana e, paradoxalmente, como sua parte mais viva. Para o homem que se sabe ser para a morte, este acontecimento está no mundo, mas ele só o conhece porque a sua própria morte está por vir. Então, morrer é o mesmo que perder o homem que ele é, porque é perder a morte. Não é a morte em si que é trágica e, sim, a vida na iminência da morte, ou a certeza de se tornar incapaz para a ação, certeza de já não poder morrer:

\footnotetext{
Enquanto vivo, sou um homem mortal, mas, quando morro, cessando de ser um homem, cesso também de ser mortal, não sou mais capaz de morrer, e a morte que se anuncia me causa horror, porque a vejo tal como é: não mais morte, mas a impossibilidade de morrer. (BLANCHOT, 1997, 324).
}

Miguilim, quando julga que sua morte estava iminente, começa a se lembrar das pequenas coisas do dia-a-dia: o rapé da avó sendo torrado e moído, o leite açucarado que lhe davam com folhinhas de hortelã, o mingau-de-fubá que tomava todas as manhãs e chora. Seus familiares pensavam que o choro era decorrente do medo do purgante que lhe fora prescrito, mas não era: o medo era de perder o seu cotidiano simples, de deixar de fazer as coisas costumeiras, perdendo com a morte a possibilidade de agir, o que equivale à possibilidade de morrer numa outra época: "Miguilim estava chorando simples, não era medo de remédio, não era nada, era só a diferença toda das coisas da vida" (p,495). Dito, por sua vez, tem medo de deixar de ser capaz, não quer morrer para ser útil a todos da família: "Eu gosto de todos. Por isso é que eu quero não morrer e crescer, tomar conta do Mutum, criar um gadão enorme" (p.516). Vivenciando em suas vidas a morte anunciada, os meninos frequentemente aludem à morte e ao medo em suas conversas. Assim, comentando sobre o Grivo, menino pobre e solitário que vez ou outra aparecia na fazenda, 
Miguilim se perguntava: “O Grivo tossia, muito. Será que ele não tinha medo de morrer?” (p.510). Esse medo de já não ser capaz é a tragédia que se anuncia para Miguilim, quando ele se julga contaminado pela tuberculose e próximo da morte. Tragédia que se anuncia ao Dito, vítima do tétano. $\mathrm{Na}$ iminência da morte, ambos demonstram temor e preocupação, porque antes do medo de deixar o mundo, é do medo de deixar a morte que padecem os dois irmãos, medo de que padece toda a humanidade.

Além dessa tragédia que é geral, de uma outra, particular e doméstica, os meninos vão tomando consciência. Tragédia inscrita no não querer dizer. Jacques Derrida, estudando o episódio bíblico de Abrão e Isaac (a ordem funesta dada por Elohim, a obediência cega do pai à lei e o silêncio que envolve a cena), encontra no silêncio dos participantes do anunciado sacrifício um caminho para a compreensão literária. Quando Isaac pergunta ao pai onde está o animal do holocausto, o pai não diz a Isaac que ele seria o cordeiro, diz, simplesmente, que Deus haveria de providenciá-lo. Abraão fala, mas sem falar, responde, mas sem responder, deixando no vazio a verdade cruel que o agente e o paciente da morte sacrificial sentem fluir das palavras não ditas, que soam como um pedido de perdão, por não se poderem verbalizar. (DERRIDA, 2000, p.117). O episódio bíblico é uma tragédia familiar em que uma lei superior (a de Deus) se faz maior que o amor (do pai pelo filho). Isaac compreende a dissimulação de Abraão. Essa compreensão silenciada o torna adulto. É uma tragédia semelhante que figura em "Campo Geral", quando palavras amordaçadas, atravessadas por reticências carregadas de significação, parecem refletir uma interrogação sempre repetida e uma sempre repetida perplexidade com o não dito, a suscitar novas questões, pois “O Dito perguntava continuação" (p.497), ou parecem ilustrar o pensamento único de todos os falantes: perdão por não poder dizer, perdão por não querer dizer, perdão se mesmo sem o querer, o segredo se diz. Na novela, tudo se resume "no parentesco que se estabeleceu entre as palavras pensadas, ausência, fala e morte" (BLANCHOT, 1987, p.106).

Quem descobre a briga entre o Pai e a Mãe é Dito, criança adulta antes do tempo, e é seu dito que dá ciência do acontecimento ao irmão: “ - Pai está brigando com Mãe. Está xingando ofensa, muito, muito. Estou com medo, ele queria dar em Mamãe... (...) - Eu acho, Pai não quer que Mãe converse mais nunca com o tio Terez... Mãe está soluçando em pranto, demais da conta.” (p.470). É precisamente o que Dito não disse, que deixou segredado nas reticências, que faz Miguilim descobrir o drama familiar: "Miguilim entendeu tudo tão depressa, que custou para endender" (p.470). As palavras encobertas, que travam a verbalização, dão ensejo a uma profundidade hiante, quando proferidas também por outros personagens. Sempre estão a encobrir e, paradoxalmente, a revelar o segredo de Terez e Nhanina. Vó Izidra, de quem se diz que enxergava no escuro, (expressão que tem um duplo sentido) expulsa Tio Terez chamando-o de Caim. A negra 
Mãitina diz "que tudo que há que acontece é feitiço..." (p.472), assim de um lado, a traição, e de outro, a inevitabilidade trágica são anunciadas nessas falas.

A concepção trágica da existência moldou o pensamento ocidental a partir de duas fontes culturais: a greco-latina e a judaico-cristã. Ambas fazem a tragédia partir de um erro. Este pode ser resultado de uma afirmação absoluta de liberdade contra a opinião comum, tragédia da desobediência, ou pode ser resultado da fatal obediência à doxa. No caso bíblico, a tragédia de Abraão é fruto de sua obediência à Lei. No caso greco-latino, decorre da ousada afirmação de um eu em bybris contra a soberana lei que organiza a vida comunitária. Em choque, agonisticamente, estarão a liberdade do sujeito e os quadros referenciais que regem seu mundo. Esse erro de origem pode passar de uma geração à outra, como herança contaminada que, desde o antigo teatro grego, gera a tragédia de família, como a dos Átridas. Sexualidade, amor e morte se justapõem na configuração trágica, submetendo as liberdades individuais a superiores poderes.

A moral do sertão é rígida no que concerne ao comportamento sexual da mulher. Há dois tipos opostos de mulher, que o sertão reconhece e admite, mas cujos territórios são bem delimitados e não intercambiáveis: a mulher doméstica, inserida no domus (casa) e submetida ao domus, pai ou marido, e a mulher-à-toa, de porta aberta ao trânsito dos homens. A avó materna de Miguilim pertencia à segunda categoria. Quando velha, Vó Benvinda só rezava e "Um vaqueiro contou ao Dito, de segredo, Vó Benvinda quando moça tinha sido mulher-à-toa. Mulher-à-toa é que os homens vão em casa dela e ela quando morre vai para o inferno" (p.478). Benvinda, ao aproximar-se da morte, reza por medo do inferno, reza como penitência ao pecado, ao erro, da juventude. O comportamento da mãe, jovem, bonita, fogosa, sonhadora, reproduz a herança maldita, o erro primordial. Parece querer seduzir quantos lhe chegam a casa: Tio Terez, Luisaltino, e até Seu Aristeu que ela considerava "um homem bonito e alto...”. A fala reticente da Mãe diz o que ela quer segredar: seu imperioso desejo. A Vó Izidra, que enxerga longe, pois era capaz "de formar profecia das coisas" (p.464), reprovava o comportamento da Mãe, porque era desobediência à lei do domus, num exercício de liberdade que contrariava a moral sertaneja. Tal como Benvinda, Izidra também julga que a reza podia afastar o Mal, porém não a reza da mulher, mas a de seus filhos inocentes, por isso convocava-os, esclarecendo o porquê da convocação: "Inocência deles é que pode livrar a gente de brabos castigos, o pecado já firmou aqui no meio, braseando" (p.478). Ao ouvir Izidra, Nhanina baixava a cabeça e ficava silenciosa, assim confirmava, pelo silêncio, seu próprio pecado, o fogo que a punha em brasa. Pelas insinuações dos envolvidos, por seus silêncios, ou pelos suspiros lastimosos de Nhanina, o pecado de origem se evidencia: "No começo de tudo tinha um erro - Miguilim conhecia, pouco entendendo" (p.466). Como Isaac, Miguilim perdera a inocência, se fizera adulto, compreendendo as lacunas deixadas pela linguagem reticente de seus 
interlocutores. Não é por acaso que a primeira alusão a Miguilim é a de que fizera sete anos e fora se crismar, receber um sinal que, no caso, é o de ter atingido a possibilidade de compreender, ao entrar na idade da razão.

A natureza sexual do erro se expõe na resposta dada pela Mãe à pergunta de Miguilim sobre como saber se uma ação era bem ou mal feita. Miguilim estava em dúvida sobre o valor a atribuir ao fato de não entregar o bilhete que Tio Terez enviara para a Mãe. Pergunta a Rosa, a Vaqueiro Zé, a Dito e à Mãe. A resposta de Nhanina é sintomática por associar prazer a pecado: "Ah, meu filhinho, tudo o que a gente acha muito bom mesmo fazer, se gosta demais, então já pode saber que é malfeito" (p.502).

Concomitantemente à compreensão de Miguilim, os leitores da novela passam a encontrar respostas que estavam suspensas em perguntas sugeridas e cuja causalidade se mostrava sempre deficiente: por que o pai só maltratava os filhos nascidos com cabelos pretos, Miguilim e Chica, e não os de cabelos ruivos como os dele, por que os irmãos caçoavam de Miguilim por ele não ter sobrenome, por que a família partiu de Pau Roxo, por que os nomes dados aos cães pertenciam a José Rocha e Julinho da Túlia que eram desafetos do Pai, por que o Pai odiava tais homens, por que Vó Izidra não gostava de Mãe, prenunciando "questão de brigas e mortes, desmanchando com as famílias" (p.473), por que os meninos pensavam que não seria boa coisa o Pai trazer para trabalhar com ele o Luisaltino, por que o Tio Terez, que gostava tanto de Miguilim, se calava quando este aludia ao Pai? Estas questões anunciam uma violência exposta e preservada em cuja presença os comentários se fazem supérfluos e inoportunos, daí os silêncios carregados de mensagens. Tudo se esclarece a partir do erro herdado por Nhanina e que as falas travadas, as palavras poupadas e os silêncios entre os ditos desvelam.

São os ditos silenciados que instauram a tragédia, criando uma estrutura "suspensa" por uma série de perguntas. Um comentário sobre o que possivelmente se passou se transforma em interrogação sobre o que poderá vir a se passar. Um passado se encena como capaz de decidir o futuro e este futuro fica suspenso pela liberdade individual sobre o que fazer com ele. O sentido de seres e atos depende de uma lei que está acima da liberdade individual para administrar passado e futuro. Essa estrutura em que tempo, liberdade individual e lei se conjugam está na raiz da tragédia (BARTHES, 1984, p.64), deixando os personagens suspensos na linguagem, temerosos diante da iminência da morte que só a linguagem pode anunciar.

"Campo Geral", assim, se decodifica em suas significações múltiplas: é "campo" onde se trava a luta entre o dito e o silenciado para a constituição do sentido, é "campo" onde batalham as emoções primárias, amor e ódio, e os imperativos hedonísticos individuais, que levam à traição, e os éticos grupais, que prescrevem a fidelidade, é "campo" onde se enterram personagens e palavras, 
e é "campo", ainda, de onde brotam vivos os ditos que tecem a estória. A novela, assim, filosoficamente, devolve ao dito sua condição primeira de logos, razão, trabalhando a tragédia do ser humano como tragédia do conhecimento: saber é descobrir-se mortal, é "a começação de desconhecidas tristezas” (p.492).

\section{REFERÊNCIAS:}

BARTHES, Roland. "O teatro grego”. In: O óbvio e o obtuso (trad. Isabel Pascoal). Lisboa: Edições $70,1984$.

BLANCHOT, Maurice. A parte do fogo (trad. Ana Maria Scherer). Rio de Janeiro: Rocco, 1997.

BLANCHOT, Maurice O espaço literário (trad. Álvaro Cabral). Rio de Janeiro: Rocco, 1987.

DERRIDA, Jacques. Dar la muerte. Barcelona: Paidós, 2000.

HOWARTH, Glennys e LEAMAN, Oliver (org.). Enciclopédia da Morte e da Arte de Morrer. Lisboa: Quimera, 2004.

ROSA, João Guimarães. “Campo Geral”. In: ROSA, J. G. Fiç̧ão Completa. Rio de Janeiro: Nova Aguilar, 1994.

SCHOPENHAUER, Arthur. Metafísica do Amor Metafisica da Morte. São Paulo: Martins Fontes, 2000. 